The University of Maine

DigitalCommons@UMaine

Publications

Senator George J. Mitchell Center for Sustainability

Solutions

$10-2013$

\title{
The Maine Vernal Pool Mapping and Assessment Program: Engaging Municipal Officials and Private Landowners in Community-based Citizen Science
}

Jessica Spelke Jansujwicz

University of Maine, jessica.jansujwicz@maine.edu

Aram J K Calhoun

University of Maine, Calhoun@maine.edu

Robert J. Lileholm

University of Maine

Follow this and additional works at: https://digitalcommons.library.umaine.edu/ mitchellcenter_pubs

Part of the Environmental Indicators and Impact Assessment Commons

\section{Repository Citation}

Jansujwicz, Jessica Spelke; Calhoun, Aram J K; and Lileholm, Robert J., "The Maine Vernal Pool Mapping and Assessment Program: Engaging Municipal Officials and Private Landowners in Community-based Citizen Science" (2013). Publications. 55.

https://digitalcommons.library.umaine.edu/mitchellcenter_pubs/55 
The Maine Vernal Pool Mapping and Assessment Program: Engaging Municipal Officials and Private Landowners in Community-Based Citizen Science

Jessica S. Jansujwicz , Aram J. K. Calhoun, Robert J. Lilieholm 


\section{ABSTRACT:}

The Vernal Pool Mapping and Assessment Program (VPMAP) was initiated in 2007 to create a vernal pool database as a planning tool to foster local compliance with new state vernal pool regulations. In the northeastern United States, vernal pools are seasonal wetlands that provide critical breeding habitat for a number of amphibians and invertebrates and provide important resting and foraging habitat for some rare and endangered state-listed species. Using participant observation, interviews, and focus groups, we examined the engagement of municipal officials and private landowners in VPMAP. Important outcomes of municipal and landowner engagement included mobilization of town support for proactive planning, improved awareness and understanding of vernal pools, and increased interactions between program coordinators, municipal officials, and private landowners. Challenges to municipal and landowner engagement included an inconsistency in expectations between coordinators and municipal officials and a lack of time and sufficient information for follow-up with landowners participating in VPMAP. Our study highlights the importance of developing relationships among coordinators, municipal officials, and private landowners in facilitating positive outcomes for all stakeholders and for effective resource management. We suggest an expanded citizen science model that focuses on improving two-way communication among project coordinators, municipal officials, and local citizens and places communication with private landowners on par with volunteer citizen scientist recruitment and field training. Lessons learned from this research can inform the design and implementation of citizen science projects on private land.

Keywords: Citizen science, Vernal pools, Conservation planning, Private land, Stakeholder, Municipal official, Landowners 
INTRODUCTION

There is widespread recognition of and concern for the growing gap between scientific knowledge and conservation action (Fox et al. 2006; Hall and Fleishman 2009; Hart and Calhoun 2010; Knight et al. 2008; Meffe et al. 2006; Ryers et al. 2010). Heightened concern for the increasing disconnect between the science and practice of conservation highlights the urgent need for new approaches to link scientific knowledge, stakeholder decision-making, and on the ground conservation outcomes.

Rather than traditional expert-driven public outreach, new models of engagement change the way scientists use scientific knowledge to inform society and change societal action (Groffman et al. 2010). Under the traditional view, expert-driven public outreach and communication was considered the most apt approach for delivering information to public audiences. It was thought that when the views of experts were better conveyed to the public, the public would understand the issues as scientists do, and public acceptance of policies and decisions would follow as a result of an alignment process (Rowe and Frewer 2000). This approach is known as the "deficit" model since it describes a deficit of knowledge that when filled is presumed to change behavior and improve outcomes (Brossard and Lewenstein 2010; Ziman 1991, 1992). In recent years, however, scholars have begun to question the merits of expert-driven approaches (Groffman et al. 2010; Nisbet and Scheufele 2009; Sturgis and Allum 2004). As a consequence, new concepts of "public understanding of science" have emerged that move away from expert-driven models to new models that stress lay-knowledge, public participation, and stakeholder engagement in science and policy-making (Lewenstein 2003). 
Conceptualized as a public engagement process, citizen science operates at the nexus between science and society and creates new opportunities for scientists to interact with the public. Citizen science is defined as "the engagement of non-professionals in scientific investigations-asking questions, collecting data, or interpreting results" (Miller-Rushing et al. 2012, p. 285). Although not a new approach (Miller-Rushing et al. 2012), citizen science is increasingly supported as a public engagement model that can bridge the expert-lay divide that exists between scientists and a local community of stakeholders (Calhoun and Reilly 2008; Meffe et al. 2006; Novacek 2008). Increasingly, citizen science programs are lauded for their ability to educate voluntary participants (Bonney et al. 2009; Danielson et al. 2005; Evans et al. 2005; Jenkins 1999; Trumbull et al. 2000), provide low-cost data collection (Crall et al. 2010; Lepczyk et al. 2005; Ingwell and Preisser 2010; Silvertown 2009; Weckel et al. 2010), and empower citizens to participate more actively in local conservation and management decisions (Calhoun and Reilly 2008; Crall et al. 2010; Kransy and Bonney 2005; Oscarson and Calhoun 2007). However, while recent studies provide important insight on the design and implementation of citizen science programs that may improve outcomes for volunteer citizen scientists and the scientific community, they do not consider the roles played by other critical constituents. Indeed, most citizen science studies focus only on a subset of volunteer participants who are actively engaged in data collection (herein referred to as "citizen scientists") and do not consider how other participants might be engaged. Most notably, few studies empirically examine the effect of citizen science programs on municipal officials and private landowners. Understanding how to engage these stakeholders in proactive conservation is critically important because most of the land in the United States is privately owned (USDA 2002), and most of the authority for land-use 
decisions is vested with local municipalities and private landowners (Dale et al. 2000). Citizen science offers an opportunity to involve these interests as key partners in local conservation planning.

However, facilitating citizen science-based surveys on private land requires an improved understanding of the complex interactions and relationships between municipal officials, private landowners, and scientific experts. Because some citizen science projects already involve private landowners and municipal officials, there is value in investigating the impact and effectiveness of these relationships and in exploring ways to enhance engagement of these key conservation partners.

Relationships with landowners have been identified as a key constraint for conducting biodiversity research on private lands (Hilty and Merenlender 2003). Unfortunately, with the exception of Brook et al. (2003) and Carr and Hazell (2006), few studies empirically examine landowner response to data collection activities on private property. Studies of landowner participation in citizen science programs typically focus on the residents who are directly engaged in voluntary data collection efforts (e.g., Cooper et al. 2007; Weckel et al. 2010). Limited attention is given to landowners with property in the study area, but who do not participate in data collection. In other words, emphasis is on landowners who actively monitor biodiversity on their own properties, and not on landowners whose primary role is to permit (or not permit) access for study by citizen scientists. Similarly, studies that address local government participation in citizen science programs usually do so only within the context of how to engage and train citizen scientists or how to use ecological data once collected (e.g., Calhoun and Reilly 2008), rather than on how to negotiate relationships between citizen scientists, private landowners, and municipal officials. Citizen science 
projects occur within a broader social context of relationships between diverse individuals and institutions, all of which can influence the conservation process. Therefore, research that focuses primarily on volunteer data collectors misses critical elements of programmatic interactions, such as those between program coordinators, municipal officials, and private landowners.

Our study considers the challenges and opportunities for more effectively engaging municipal officials and private landowners in volunteer-based citizen science activities on private land. Our research focuses on a citizen science program jointly initiated by the University of Maine and Maine Audubon Society-the Maine Vernal Pool Mapping and Assessment Program (VPMAP). VPMAP works collaboratively with local municipal officials to map and conduct ecological assessments of vernal pools on public and private land using trained citizen scientists. Within the context of this program, we define "citizen scientists" as community volunteers who are trained by professional scientists to conduct vernal pool assessments. In this study, our focus is not on the vernal pool citizen scientists. Instead, we examine the participation of municipal officials and private landowners in VPMAP. Municipal officials are critical partners in brokering relationships between program coordinators, volunteers, and landowners. While this approach of partnering to administer a large-scale project at the local level is one that is becoming an important model in the field of citizen science, it has not yet received much scholarly attention.

Using VPMAP as a partnership model, our objectives were to describe how VPMAP structured interactions with municipal officials and private landowners in the context of vernal pool conservation planning, and to document the perceptions and experiences of municipal officials and private landowners in Maine towns that were participating in 
VPMAP. Author and ecologist AC coordinates VPMAP with assistance from a research associate. While the intent of this study was to examine landowner and municipal perspectives, and this paper primarily presents our social science research, we also include author reflection upon VPMAP program design and implementation. Overall, our goal was to understand and improve working relationships necessary to facilitate citizen science-based surveys on private land. We offer insights on the challenges and opportunities for working with municipal officials and private landowners to enhance the impacts of citizen science on individuals, communities, and local conservation planning initiatives. Lessons learned from our research can help to inform the design and implementation of citizen science projects on private lands that require local participation and cooperation of both municipal officials and private landowners.

\section{STUDY CONTEXT}

We chose vernal pools as a model system for natural resource management on private properties as vernal pools are widespread yet often overlooked for conservation, and are the focus of relatively new and controversial legislation in Maine. Vernal pools in the northeastern U.S. are small ( $\backslash 0.5$ ha), seasonal wetlands that provide critical breeding habitat for a number of amphibians and invertebrates and important resting and foraging habitat for many rare and endangered species (Calhoun and deMaynadier 2008). In Maine, a subset of exemplary vernal pools, Significant Vernal Pools (SVPs), are regulated by the State under the Natural Resources Protection Act (NRPA; 38 M.R.S.A. §§ 480-A to 480-Z). However, unlike other natural resources protected by state laws, vernal pools, because of 
their size and ephemeral nature, could not be easily inventoried or mapped. In 2007, when the Maine State Legislature passed the vernal pool law, vernal pools were not mapped, and this posed a significant challenge for regulatory compliance. In response, the goals of VPMAP were to: (1) develop a map of vernal pools, and particularly SVPs, in partnership with interested local towns with the goal of submitting data to the State database; (2) provide towns with a map and data on pools for use as a decision-making tool in planning and development activities; and (3) raise public awareness of the value of vernal pool resources by educating citizens through hands-on engagement in pool assessment and documentation. VPMAP was designed to reduce uncertainty in development proposals by offering landowners a free vernal pool assessment to determine whether a potential vernal pool (PVP) meets the biological criteria for "significance" under NRPA. "Significance" is determined by threshold egg mass counts of pool-breeding amphibians (e.g., wood frogs, spotted salamanders, and blue-spotted salamanders) during the peak breeding season in the spring, or the presence of fairy shrimp and/or an endangered or threatened species. PVPs are first identified remotely by aerial photography, but then require field assessments in the spring by a citizen scientist, consultant, agency biologist, or other qualified individual to determine whether they meet the above biological criteria of an SVP. At the time of this study, VPMAP had engaged 12 Maine towns and over 140 volunteer citizen scientists. It logged over 3,300 volunteer hours over two to three field seasons, and gained permission to access over 400 privately owned parcels (Calhoun, unpublished data).

Program coordinators, municipal officials, citizen scientists, and private landowners play different roles in VPMAP. Researchers from the University of Maine (led by author AC) coordinated the project. Coordinators invited towns either by email or phone to participate 
in VPMAP. After towns agreed to participate, coordinators guided municipal officials through the process of mapping pools. They provided maps and resource materials for field assessments, led public information sessions, trained volunteer citizen scientists, and helped the towns to process and submit data to the State (see Morgan and Calhoun 2013). It was expected that the towns would take the lead on recruiting citizen scientists, host citizen science training sessions, assemble volunteer materials, and solicit land-owner permission for citizen science assessments. Towns would also serve as a clearinghouse for the support materials and data forms and files. In return, the towns would receive an advanced planning tool (a free vernal pool assessment and digital database) to help them meet the regulatory requirements for vernal pools. VPMAP was intended as a town-driven process, and while towns could pursue the adoption of stricter local regulations, no further vernal pool work was expected or required.

Landowners with PVPs were invited to participate in VPMAP by permitting access to their property and/or by attending a vernal pool information session. Invitations to participate in VPMAP (herein referred to as the "landowner letter") were written and sent by the participating town. Once a landowner returned a signed permission form allowing property access, a trained volunteer citizen scientist conducted a field assessment of the pool in the spring, counted amphibian egg masses, and recorded other relevant biophysical data. No assessments were conducted on private land without landowner permission, and landowners were invited in the landowner letter to accompany citizen scientists on field visits to their property.

We examine VPMAP to provide information on how to structure citizen science programs and particularly how to improve relationships among program coordinators, 
municipal officials, and landowners to enhance outcomes for individuals, local communities, and vernal pools. This information can be readily transferable to other citizen science projects dealing with significant natural resources that aim to collect data on a wide array of natural resources that occur predominantly on private land.

\section{METHODS}

Our study area included 8 of the 12 Maine towns participating in VPMAP (Fig. 1). Towns selected were located in rapidly developing areas of Maine within $20 \mathrm{~km}$ of either Portland or Bangor, two of the state's largest cities, and faced similar development pressures. To gather data on municipal and landowner perspectives and experiences, we used three qualitative research methods: (1) participant observation (Bernard 2006; Glesne 2006); (2) in-depth semi-structured interviews; and (3) focus groups. By using multiple methods to examine landowner and municipal perceptions of vernal pools and VPMAP, we confirmed our emergent findings (Merriam 2009) and reduced the risk that results reflected some “methodological artifact" (Bouchard 1976, p. 268).

Participant Observation

We attended five municipal planning meetings organized by program coordinators to discuss steps involved in launching VPMAP, and six citizen science training sessions involving public presentations on vernal pool ecology, amphibian egg mass identification, and the field assessment process. Public presentations also included field exercises where citizen 
scientists learned to identify and count amphibian egg masses and to document other important biophysical features of vernal pools. Interested volunteers, landowners, and the general public were invited to attend these sessions.

Semi-structured Interviews

We conducted 11 semi-structured interviews with elected or appointed officials from eight municipalities participating in VPMAP. We selected municipal officials purposively (Bernard 2006) through document analysis, attendance at VPMAP planning meetings and public information sessions, and by a snowball sampling technique-a method often employed for identifying and selecting individuals in a network (Neuman 2000). Interviews with municipal officials were open-ended and covered a range of topics including personal and organizational background, municipal knowledge and experience with vernal pools, and municipal involvement with VPMAP (Appendix 1). Specifically, we asked about why their town chose to participate in VPMAP, their role in the project, and whether they received feedback or followed-up with landowners who received the landowner letter or participated in VPMAP. We also asked about their perceptions of VPMAP benefits (short-and long-term) and about challenges faced in program implementation.

We interviewed nine private landowners with one or more PVPs on their property. Landowners with PVPs were selected from a subset of four participant towns (Brunswick, Topsham, Freeport, and Windham). These four towns were chosen because they are all located near Portland and used a similar landowner letter to notify landowners of the PVP(s) on their property and to request permission for a citizen scientist to conduct a vernal pool 
assessment. Landowners interviewed were selected purposively. Municipal officials identified landowners who might be interested in speaking with us about vernal pools on their property. Two additional landowners were identified during the study. We conducted interviews at participant's homes and businesses, and at local coffee shops and public libraries. One interview was conducted by phone. Of the nine landowners interviewed, all but one had permitted access to their property for a PVP assessment. Interview questions addressed general biographical and property information, general knowledge and experience with vernal pools, and individual experience with VPMAP (Appendix 2). The primary purpose of these interviews was to identify major themes related to the landowner's property and vernal pools. Analysis of key informant interview data provided the basis for focus group questionnaire development.

Focus Groups

We conducted eight landowner focus groups-two in each of the four focal towns. We selected focus group participants randomly from a list of landowners with PVPs obtained from VPMAP's municipal partners. We used a factorial research design (Bernard 2006) where each focus group represented a homogenous group of landowners with respect to permission status. Within each study town, one focus group included private landowners who gave permission to be included in the citizen science study. The second focus group included those landowners who did not return the permission form to allow a PVP assessment. We separated focus group participants into homogenous groups because we wanted to fully represent both participating and non-participating landowners. This 
arrangement created a non-confrontational environment for dialog in the company of others with similar opinions on a given issue (Kamberelis and Dimitriadis 2005).

Focus group questions probed landowner knowledge, awareness, and views on vernal pools and vernal pool regulations, and landowner awareness and perceptions of VPMAP (Appendix 3). To stimulate discussion of landowner experience with VPMAP, we provided landowners with a copy of the original landowner letter sent by their respective town informing them of the PVPs on their property.

Interviews and focus groups were audio recorded, transcribed, and then stored and analyzed using NVivo 8 Qualitative Research Software. For qualitative analysis, we used a method of coding linked closely to grounded theory (Glaser and Strauss 1967; Strauss and Corbin 1990) that focused on identifying themes and categories as they emerged inductively from the transcripts related to landowner and municipal decision-making and landowner and municipal experience with vernal pools and VPMAP. Codes initially consisted of highlighted words and phrases isolated from the text (Strauss and Corbin 1990). We then compared codes, made note of interrelationships, and collapsed related categories, patterns, and themes as deemed appropriate (Saldaña 2009).

\section{RESULTS}

Results are grouped according to participant and interview type (i.e., municipal interviews, landowner interviews, and focus groups). Data from our observations at planning meetings, public meetings, and citizen science training sessions are used to support themes that emerged from municipal and landowner interviews and landowner 
focus groups. Initial codes emerging from observations, interviews, and focus groups were recoded and organized under broad thematic codes: (1) motivation for participation in VPMAP; (2) knowledge and awareness of vernal pools and vernal pool regulations; and (3) experience with VPMAP.

Municipal Interviews

Municipal officials interviewed included three natural resource planners, four town planners, two town managers, one conservation commissioner, and one geographic information systems (GIS) specialist. To preserve confidentiality, we do not differentiate between categories of municipal officials (e.g., town manager, town planner, and natural resource planner), but rather group them under the general label "municipal official."

Municipal Participation

Municipal officials identified key reasons for their town's motivation to participate in VPMAP. We draw on interview data to describe three categories of responses: (1) perceptions of VPMAP as a proactive planning tool, (2) perceptions of VPMAP as a non-adversarial approach to conservation planning, and (3) perception of VPMAP as a means to garner financial and technical assistance to help landowners and municipalities comply with the new state vernal pool regulations.

In most of the study towns, municipal officials had to seek support to join VPMAP from their town council or other town-elected decision-making body. In translating perceived 
benefits of VPMAP to their town decision-makers, municipal officials focused on the potential benefits of proactive planning. One municipal official said:

What I tried to stress was that...this is a law. People are going to have to deal with vernal pools, and if we can proactively identify them, we are going to assist people. We are going to ease development by knowing ahead of time what is or is not on their property. And I think that was really the selling point.

Another official we interviewed described VPMAP as "less threatening" because it was not "self-initiated" by the town. Because the program was perceived as non-adversarial, he was able to "convince all decision-makers that it really was voluntary and potentially helpful information for anybody that had an interest in developing their property or knowing what the limitations would be in the future for planning purposes."

Support for the program was also attributed to the technical and financial support offered by VPMAP. One municipal official found VPMAP attractive because of what he explained was a "very reasonable price" for a GIS data layer. Others spoke of the opportunity to receive funds through a grant administered by the Maine Audubon Society as the impetus for their involvement.

Municipal Knowledge of Vernal Pools

VPMAP offered opportunities for municipal officials to learn about vernal pools. Municipal officials engaged with coordinators at project planning meetings, and also attended citizen science training sessions. Training sessions were led by the coordinators and held in study towns prior to spring field assessments. During these sessions, municipal 
officials asked questions about vernal pools and sat in on presentations about vernal pool ecology and management. When asked about the extent of their knowledge and understanding of vernal pools before VPMAP, most municipal officials admitted to having minimal knowledge. One municipal official with "very little" previous knowledge of vernal pools "just associated them as some part of wetlands." Another said:

I knew virtually nothing about vernal pools before this project. I had no idea that these were so sensitive to the environment, that they dried out, potentially dried out every year and that they provided so much biomass for other things to live on.

Some municipal officials also learned "hands-on" how to conduct a biological assessment of a vernal pool in the field. One municipal official who actively participated in the citizen science training sessions spoke of the knowledge she gained by partnering with VPMAP coordinators:

Even before the project was started I was pretty aware of what a vernal pool was and the role in the ecosystem. I had never been trained in how to identify specific egg masses ... I've learned a lot of little details I didn't know.

Municipal Experience with VPMAP

Data on municipal experience with VPMAP reflected positive perceptions of municipal involvement and also perceived challenges faced in program implementation (Table 1). 
A key theme emerging from our data was increased interaction between project participants. The process of VPMAP implementation created new opportunities for interaction between program coordinators, municipal officials, and private landowners. Often joint meetings were held where two or more towns participated. At project planning meetings municipal officials and coordinators worked together to organize citizen science training sessions and to carry out various aspects of VPMAP (e.g., design of the landowner letter, and compilation of PVP maps, field data sheets, and other resources for volunteers). Planning meetings provided an opportunity for coordinators to solicit feedback from municipal officials and work out kinks in project implementation. For example, in an early stage of the process, one municipal official helped researchers redesign field data sheets to make them more "user friendly" for citizen scientists. Based on her on-the ground experience with volunteers, the official had a better understanding of how to reduce the workload for citizen scientists to keep them interested and involved while at the same time insure the collection of the biophysical data needed to meet program objectives.

VPMAP also created new opportunities for interaction between municipal officials in neighboring towns. During planning meetings municipal officials shared experiences and ideas for project publicity and for recruiting and training citizen scientists. For example, at one meeting, a town official cautioned other municipal officials to be selective about their volunteers - she had learned (the hard way) that fewer motivated volunteers led to better outcomes than an outpouring of volunteers who did not follow through on assigned tasks. These observations were supported by our interviews with municipal partners. One official commented on how much he had learned about coordinating the mapping process from a 
planner in the neighboring town who shared her templates for the landowner letter, press releases, and other VPMAP materials.

VPMAP activities also fostered dialog between municipal officials and landowners. In particular, the landowner letter was a catalyst for increased interaction between officials and landowners with PVPs. One municipal official explained how several landowners had contacted her in response to the letter. She said, "I probably had 10 people come in...They wanted to look at it [the PVP map] they wanted to know more." Echoing a similar experience, another official said, "Some people would come in and meet with me, look at the map, and try to understand where the pool was."

\section{Challenges}

Communication challenges emerged as a dominant theme from municipal interview data. These challenges largely arose from inconsistencies between municipal and program coordinator expectations of VPMAP. One municipal official explained how they had decided to join VPMAP without a clear understanding of what the project would entail in terms of coordination and workload (e.g., recruiting volunteers, scheduling training sessions, writing and disseminating the landowner letter, etc.). His initial impression was that:

For $\$ 2,000$ we would be getting a list of potential vernal pools, a GIS layer. And that was really going into it what we thought the extent of it would be... Once we got the GIS layer and communicated a little bit more with the folks at the university it was kind of a packaged deal. There is work to be done. So that was unexpected...I came back from that meeting...it was 
like 'OK, we've got a lot of work to do actually.'

Another municipal official felt that program coordinators did not clearly articulate project components (e.g., when the landowner letters needed to be sent out, timing of PVP assessments), and she was unclear as to her specific role in the process. She was under the impression that she would "generally oversee the effort, but that the hands-on training and field work was going to be done by the conservation commission and any volunteers that they were able to secure." But what she ultimately experienced was a failure in communication about who was leading the project. She explained how she "basically starting managing the project," went to the trainings, mailed out the landowner letters, and recruited citizen scientists. In describing her role, she expressed considerable frustration about the amount of unanticipated work and responsibility. She explained:

All of a sudden it was this extreme urgency to get people [citizen scientists] out in the field, get the maps, get them out there. And the maps were not ready for the training kick-off meeting... and it was like, to be honest, I didn't know we needed them for this meeting. I thought this was just to go out, see what a vernal pool looks like, see what the egg masses look like... to be honest it was really quite a debacle.

Another municipal official in the same town summed up the experience and "confusion" with their training sessions as a "breakdown in communication of what the expectations were." He said:

I really think there was a disconnect...[the coordinator] might have thought she relayed the information on numerous occasions, but [our municipal official] didn't feel like she was fully understanding what the expectations were. 
Communication issues also emerged from discussions of municipal-landowner interactions. Repeatedly during our study, we heard from municipal officials that they simply "just haven't had time" to follow-up with landowners. Municipal officials also felt that they did not have sufficient information to translate project outcomes with participating landowners. They expressed concern about what they perceived as an uncertain and lengthy process of determining the "significance" of PVPs. Once data were collected by community volunteers and entered by the municipal official or their staff into a database, it was sent to the Maine Department of Inland Fisheries and Wildlife (IF\&W) for review and a "significance" determination. One municipal official said, "I'm really worried about the process of figuring out which pools really are significant and getting that information out to volunteer [landowners]." She felt she had an obligation to share results of the vernal pool assessment with landowners, but that the process in place would not enable her to share results in a timely fashion. Similarly, another municipal official was concerned about the potential for "disconnect" between the data collected during a PVP assessment that "meets the criteria" for significance (e.g., meets or exceeds the specified number of egg masses) and what is ultimately decided at the state level. He was concerned that this discrepancy could warrant further studies by the state to verify the findings from the citizen science assessment, and because he was under the (false) impression that there is "only one guy from Department of Environmental Protection [DEP] in Portland doing these [assessments]," this could take considerable time. In the meantime, he admits he is uncertain of what he can "do for folks - closing the loop kinda thing." He said, "I can say, 'you met or didn't meet the criteria,"'” but beyond that he wasn't sure what he would communicate to landowners. 
Landowner Interviews and Focus Groups

Of the private landowners interviewed, three were female and six were male. Six of the interviewed landowners resided on the property with the PVP, and two lived in towns neighboring the parcel with the PVP. One inter-viewed landowner was an absentee owner. Landowners represented a range of professions, including a local business owner, local politician, firefighter, and self-employed contractor. Four landowners were retired. Focus group participants were evenly split between males and females $(n=48)$. Of these, 28 were VPMAP-participating land-owners and 20 were non-participating landowners. The age of focus group participants ranged from 39 to 77 years old. Acreage owned ranged from less than one acre to 500 acres. Residency ranged from 5 to 51 years. Focus group participants included farmers, realtors, daycare providers, physicians, nurses, sales representatives, small business owners, a stay-at-home mom, and bus driver. At least half of the participants indicated that they were retired. All but two lived on the parcel with the PVP, but all landowners lived in the study towns.

Landowner Participation

We identified key reasons for landowners' decision to participate or not in VPMAP through our interviews and focus groups. Landowners who agreed to participate (herein referred to as "participating landowner") cited the personal benefits they hoped to gain from their involvement. These participating landowners viewed VPMAP as a resource for information about their property, as a way to facilitate future development of their 
property, and as a tool for conservation.

Participating landowners were interested in receiving information about PVPs on their property, either because they were curious or because they had plans to sell or develop. One participating landowner said, "I would just like to know the implications as it relates to the vernal pool were I to decide to sell any of the land." The fact that vernal pools received legal protection in 2007 motivated some landowners to participate. A participating landowner said, "if it's legislated as to a vernal pools being protected, then you're in much worse shape if you go and do something and then end up paying fines." Another participating landowner was interested in putting a shed on her property. She said, "I knew it was going to be near where they thought the pool was. So I really felt like, if I didn't have them come out and look, they were going to hold up the building permit on the shed. VPMAP offered landowners interested in developing a way to obtain free information about a PVP on their property rather than wait for the determination "at their own expense."

Participating landowners with no plans to develop their property viewed VPMAP as a way to support conservation. In general, these landowners viewed vernal pools as an important resource, and they supported the mapping project because "you can't protect something if you don't know it's there." They participated in VPMAP to "protect the environment" and to better understand what "our stewardship should be." One participating landowner viewed VPMAP as a way to control development in their town. She said:

From my point of view [my town] is pro-development. So, I was, first of all surprised that my town signed up for [VPMAP]. And my second thing was: Oh well. Maybe this will slow my town down! 
Landowners who did not participate in VPMAP (herein referred to as "non-participating landowners") cited several reasons for this. Fear of regulation, negative perceptions of citizen scientists, lack of time and knowledge of the program, and the belief that landowners are the best stewards of their land were commonly listed reasons. A non-participating landowner said, "If you have a survey that shows a vernal pool, then this is like somebody coming along and saying the plague exists here. Do not touch." While some non-participating landowners feared that a finding of "significance" would interfere with their property rights and limit what they could do with their land, others did not participate because of what they viewed as government interference. For example, one non-participating landowner said, "[The vernal pool] does its thing and I respect that, but I know enough to leave it alone. I don't need someone to tell me I can't do something, that's all."

Some non-participating landowners voiced concerns about the credibility of vernal pool assessments conducted by community volunteers:

One of the problems that I found when the town came out and requested that we join this vernal pool study was the fact they indicated that they were hiring a bunch of college kids to do these wetland things. All I can think of is that the people they are hiring are already bent in the direction of conservation so they have their slanted viewpoints, and these are people that think...half a day training and all of a sudden they're going to be experts on vernal pools.

While some non-participating landowners viewed citizen scientists as "tree huggers" concerned with protecting wildlife on other people's property, other non-participating 
landowners did not have a problem with the use of trained volunteers. A few of those we interviewed attributed lack of time to their decision not to participate. Others had no recollection of the invitation to participate in VPMAP and had no previous knowledge of the program.

Landowner Knowledge of Vernal Pools

Our analysis of interview and focus group data showed that VPMAP raised awareness and visibility of vernal pools among landowners with PVPs. For many non-participating and participating landowners, the landowner letter was their first introduction to the term "vernal pool" and to the new state regulation. Landowners told us that before receiving the letter they had simply referred to wet areas on their property as "little puddles in the woods" or more commonly as "frog ponds." After receiving the letter, one landowner indicated that they now had a "vague idea" of vernal pools "based on something I read [in the letter] having to do with what types of species exists in the body of water." Another landowner said, "I mean I knew about them before. But not a lot of detail. And then when I got the letter, then I looked them up and read more about them." Thus, for many of the landowners we spoke with the landowner letter prompted them to find out more about vernal pools. The landowner letter also helped landowners make the connection between vernal pools and their property. One landowner said "I think I knew what a vernal pool was, but I didn't categorize any of the land on my property as having a vernal pool, so - once I read the letter I said, 'Oh yeah, I guess so."'

Both participating and non-participating landowners interviewed indicated an 
awareness of the vernal pool regulations, but had little understanding of what would be subject to regulation under the new law. From the land-owner letter, landowners understood that if they had a SVP, they would need a permit before they could develop. However, most admitted, "I don't even know what that means." While some landowners vaguely understood that "significance" had something to do with frogs and salamanders in the pool, most (both participating and non-participating landowners) wanted clarification on: "What is significant? How is a plain old vernal pool different from a significant vernal pool?" They felt there was a lot of confusion and conflicting definitions offered by those regulating vernal pools. Landowners were also under the (false) impression that if you have a vernal pool, "250-feet in all directions - you can't do nothing around it."

Non-participating landowners also expressed concern about the uncertain impacts of VPMAP on their land management objectives. They were concerned that if they signed up for the project, their property would be more heavily regulated. Landowners also did not understand the "bottom line" purpose of VPMAP. As an example, one landowner said, "I just didn't see a great deal of merit to the whole thing and I didn't understand the end objective terribly well." Some questioned what the town planned to do with the information collected by the volunteers.

Landowner Experience with VPMAP

Data on landowner experience with VPMAP reflected the positive experiences of participating landowners and also the more critical impressions of both participating and nonparticipating landowners (Table 1). 
Positive Perceptions

As a part of VPMAP, landowners were invited to accompany the citizen scientist(s) who was conducting the assessment of the PVP on their property. One participating landowner described a positive experience with the citizen scientists who assessed the pool on her property:

It was interesting...they came to the house first and talked with me...and afterwards they came back and they seemed very excited about this shrimp they had found...They were telling me about this find among other things that they had found.

Another participating landowner who joined the citizen scientist on a site visit shared a similar experience:

I really liked it. We had three different places he was looking, and in each place were different frog's eggs and salamander eggs. And he showed me the difference and I was all excited! I even wrote some of it down. I thought it was really interesting. And when [my husband] came home, I said, 'This is so exciting! Did you know we have this and that?'

We found that few landowners took advantage of the opportunity to join citizen scientists on site visits. Participating landowner's attributed a lack of time and/or interest to their decision not to accompany volunteers in the field. They also cited logistical constraints. One participating landowner said:

The woman who was trying to come back to my pool this year - we kept playing phone tag. Then I just gave up because I didn't have time to keep 
trying to call her.

This was consistent with data from municipal interviews that identified scheduling difficulties with citizen scientists as one reason accounting for the low level of landowner involvement in the PVP field assessment. Participating landowners could request a phone call or email informing them of the exact day when a volunteer would be surveying their PVPs. However, one official said that "maybe only a handful" of landowners accompanied volunteers on field assessments because "the volunteers only had so much time they could get this done and if they [the landowner] weren't available, then sorry." Again, this is consistent with the experience of many participating landowners.

\section{Challenges}

Citizen science training sessions provided an opportunity for landowners to learn more about vernal pools and VPMAP. However, we found that public information sessions primarily drew community volunteers who considered these meetings a core part of their citizen science training. In general, there were low levels of landowner participation at the public information sessions. Based on our observations, informal conversations with attendees, and later meetings with municipal partners, we approximated that less than one-quarter of those in attendance were landowners. Most landowners (both participating and non-participating) we interviewed (individually or during focus groups) did not recall receiving the invitation to the public information session included in the landowner letter.

Landowners in our study shared feedback on VPMAP, including the landowner letter, public information sessions, and communications on project outcomes. Many focus group 
participants (both participating and non-participating landowner groups) found the tone of the letter objectionable. Non-participating landowners felt that the letter served only to announce the adoption of vernal pool regulations by the state and to defend the town's decision to map the pools. In the perception of both non-participating and participating landowners, the letter was not written to elicit their support or to involve them in the planning process. One participating landowner in our focus groups said:

I was affronted...there was a tone in the letter that was bureaucratic...it kind of says, 'We've already passed the rules. And you guys can help out and get a free survey. Or, if you want to develop later, you're going to pay through the nose. And you're gonna have a hard time convincing us of your ability to do anything with your property.

Similar to municipal officials, participating private landowners were also frustrated by a lack of communication on project outcomes. When reviewing the landowner letter during a focus group, a participating landowner pointed out:

Bold print. This letter will inform you about a free opportunity to learn if your property contains a significant vernal pool. To wit, nobody's heard.

Similarly, when asked if he received feedback on the PVP assessment that was conducted on his property, another participating landowner replied:

Zero. I agreed to it, but nobody ever came back and said what they found or even if they went there. I don't know.

One participating landowner said, "It's like - just that follow-through just seems to be totally absent." Another landowner said that he had participated in the project "in good faith" and was frustrated by the length of time it was taking for the town and DEP to make a 
determination regarding the PVP on his property. For a husband and wife participating in VPMAP who were in the process of negotiating a conservation option with a land trust, there was an urgent need for a determination on the PVP. "We have heard nothing. It's just a problem," they said in their interview. They elaborated:

If we can't find out if they are vernal pools, then we have to change all the [legal] agreements [on house lots]. We need to know. Stop screwing around.

The couple were told that their town planner was trying to get information from DEP but that "all he found out was that they weren't saying whether it was a significant vernal pool until they have categorized all the vernal pools or something-so, next year, or sometime." Unfortunately, this timing would be after their option agreement with the land trust had expired, potentially costing them more money in legal and administrative fees as they negotiated another option.

\section{DISCUSSION}

In VPMAP, municipal officials and private landowners play very different roles, yet the success of the community-based citizen science program in accessing and mapping PVPs ultimately depended on their mutual, sustained sup-port, and participation. Indeed, no PVP assessments could be conducted on private land without landowner permission. Due to the number of towns involved and the fact that coordinators did not live or work in the project areas, municipal support was also critical for program adoption and implementation (e.g., garnering support, galvanizing volunteers, organizing training sessions and data entry). Our 
research offers insight into the challenges and opportunities for working with a wider network of municipal officials and private landowners on community-based citizen science programs that address conservation planning and management issues for a broad array of natural resources on private land.

Benefits of Municipal and Landowner Engagement

In studying the engagement of municipal officials and private landowners in VPMAP, we revealed promising outcomes of citizen science activities. These outcomes supported the benefits of citizen science widely reported in the literature. Some studies suggest that citizen science offers the opportunity to collect more data at a lower cost (Crall et al. 2010, Lepczyk et al. 2005, Ingwell and Preisser 2010, Silvertown 2009; Weckel et al. 2010), and while our research did not conduct a cost-benefit analysis, it did suggest that municipal partners valued the technical and financial benefits of VPMAP (e.g., infusion of funds for mapping, and expertise to guide assessments). Information collected by VPMAP on pool significance was needed by town decision-makers for compliance with vernal pool regulations, and VPMAP offered towns a lower cost option (and landowners a free option) for obtaining these data. In addition, the use of citizen scientists increased the number of pools that could be assessed with available funds. With hundreds of PVPs in the VPMAP, SVP assessments would not have been possible without the support of the volunteer citizen scientists.

Citizen science also offers a promising opportunity to improve scientific literacy among participants (Danielson et al. 2005; Jenkins 1999; Trumbull et al. 2000). In our study, we 
found that municipal officials gained a new (or enhanced) understanding of vernal pools by interacting with program coordinators, and that private landowners became more aware of PVPs and SVPs on their property and in their town. Because our study did not quantify the level of knowledge among landowners and municipal officials, our study is limited in the conclusions that can be drawn about pre-and post-knowledge among VPMAP participants. Thus, future studies should consider quantitative methods to gather these data through pre-and post-participation interviews or surveys.

Another benefit of citizen science programs such as VPMAP is that they provide data relevant to local conservation and management issues (Danielson et al. 2005). Vernal pools were a salient concern in our study towns. Indeed, many of the VPMAP towns were dealing with conservation and development issues related to vernal pools, and thus were open to the idea of VPMAP as a proactive planning tool that could reduce uncertainties in development decisions. VPMAP could help towns and landowners determine what permitting they would need without having to hire a consultant or engage in a potentially lengthy permitting process. VPMAP could also enhance municipal capacity to plan for conservation and development activity in the future. At a minimum, participating towns would receive a vernal pool map database that could be used by planning boards, conservation commissions, and other entities to evaluate development proposals on a case-by-case basis. A critical first step in promoting use of citizen science data in town decision-making processes, however, is building resilient relationships between coordinators, municipal officials, and other local cooperators. By working with towns on data application, coordinators gained a better understanding of municipal data needs. For example, solicited feedback by university-based program coordinators from VPMAP towns 
has contributed to an active research program at the University of Maine funded by a National Science Foundation EPSCoR grant that is assessing the economic ramifications of vernal pool conservation on private land and helping regulators, towns, and the development community devise new town-specific regulatory approaches.

Lastly, citizen science programs can empower citizens to participate more actively in local conservation and management decisions (Calhoun and Reilly 2008; Crall et al. 2010; Kransy and Bonney 2005; Oscarson and Calhoun 2007). After the social science fieldwork was completed for this study, vernal pools were once again catapulted to the center of intense political debate in Maine. With a change of gubernatorial administration in January 2011 to a more pro-business, anti-environmental regulation agenda, the vernal pool regulations became the subject of intense political scrutiny. Topping the list of the new administration's "red tape" regulatory reforms, the vernal pool regulations were a target of regulatory rollbacks with the goal of improving the business climate in Maine. At a series of public hearings and legislative working groups in 2012, participants in VPMAP (municipal officials, landowners, and community groups) testified against regulatory rollbacks and spoke to the importance of vernal pools and VPMAP. To date, political efforts to reduce the protected zone around vernal pools have failed to pass the Maine State Legislature, and vernal pools remain protected as Significant Wildlife Habitat under the NRPA. Perhaps this can be attributed to heightened public awareness and knowledge of vernal pools that we noted in our study as well as significant coordinator outreach efforts, public participation in citizen science-based activities, and well-publicized scientific findings. 
Participatory strategies are attractive because they are expected to temper the confrontational politics that often typify traditional "top-down" regulatory programs and policies (Beierle and Cayford 2002; Busenberg 1999). For private landowners in our study, however, VPMAP continued to raise fear and elevate conflict that already surrounded vernal pool regulation in Maine. Landowners expressed concern about the uncertain impacts of VPMAP on their development options, and they were particularly worried that, if a SVP were identified as part of VPMAP, their property would be more heavily regulated.

Results from our study suggest that some landowner concerns may be attributed to landowner misunderstanding of vernal pool regulations and to ineffective communication among regulators, municipal officials, and coordinators. In our study, communication with landowners occurred primarily through the landowner letter, at public information sessions, and/or interactions with municipal officials. Few landowners attended the information sessions, and for many landowners the landowner letter was their only interaction with VPMAP. While the landowner letter served to improve landowner understanding of vernal pools beyond the conception of "little puddles in the woods" and "frog ponds" to a biological definition of vernal pools that dealt with "species" and "egg masses," landowner understanding of vernal pools, the regulations, and the overall purpose of VPMAP were limited. Land-owner frustration with the regulations and VPMAP may also be a reflection of their general concerns with "property rights" and the potential economic impacts of vernal pool regulations (Jansujwicz et al. 2013). Future communications should be designed to ease landowner fears and more clearly articulate the details of the regulation and what it means for an individual landowner. Program coordinators have begun to address this need by 
developing fact sheets with "most frequently asked questions" about vernal pool regulations for use by planning boards, developers, politicians, and local citizens. These materials were developed in collaboration with state and federal regulators.

Another key challenge we identified was communication barriers that may have implications for the design and implementation of other citizen science initiatives aimed at conserving natural resources on private property. Interactions with private landowners through the landowner letter, public sessions, or meetings with municipal officials were primarily for the purpose of information dissemination where information (e.g., PVP maps) was packaged and delivered to landowners. Because communication was largely one-way (e.g., public information session and landowner letter) or infrequent (e.g., landowner interactions with municipal officials and citizen scientists), the ability to engage landowners and mobilize knowledge-to-action was reduced (Cash et al. 2003). The landowner letter only engaged landowners at the beginning of the mapping process, and landowners felt as if they were consistently left out-of-the-loop when communicating project outcomes. This lack of communication with VPMAP-participating landowners may have limited the ability to influence individual land management behavior and represents a significant missed opportunity. For example, one landowner who participated in VPMAP said of the vernal pool on her property:

We're trying to dry it out. I've planted weeping willows, and we've had the trench dug out to get rid of the water. Because it just stands in the spring, and it stinks, and it's dirty. And so we're trying to get drainage out of there and get rid of it.

The absence of continuous engagement limited the ability to understand how 
landowners perceived ecological findings from PVP assessments and how they acted upon scientific information in practice. Active, iterative, and inclusive communication between experts and decision-makers is crucial for mobilizing knowledge to action (Cash et al. 2003) and improving relationships with landowners to enhance conservation outcomes on private lands (Carr and Hazell 2006). For citizen science to have an impact on improving stakeholder relationships, and on enhancing knowledge and understanding of the targeted resource, program coordinators and municipal officials will need to continuously engage with landowners to ensure that the information they produce is salient to landowners (e.g., matches their land management objectives), and that information produced is translated to landowners in a timely and effective manner to inform their decision-making. Improving communication with landowners would greatly improve VPMAP's social and environmental outcomes.

In our study, communication issues also strained early relations among coordinators and municipal officials. Municipal officials were attracted to the utility of a "free" digital data layer that would help their town with compliance issues related to the new vernal pool regulations. In some cases, the municipal partner did not realize the extent of commitments and responsibilities involved in obtaining and organizing those data, and these differing expectations caused tension. This trend was exacerbated by some municipal officials "inheriting" the project putting them at the disadvantage of not having been involved in the original conversations and trainings with coordinators. Timelines and methods for communicating PVP assessment results to landowners were also not clearly understood by either participating landowners or municipal officials. These results highlight the need for program and municipal coordinators to better communicate program goals and 
responsibilities to all the municipal officials involved and to include landowners in these communications. Importantly, these results also highlight the need for a more systematic documentation of program coordinator perspectives. In addition to landowner and municipal perceptions, understanding the experiences of program coordinators is useful for the more effective design and implementation of VPMAP and other community-based citizen science programs and should be further explored.

In response to municipal and landowner experiences, coordinators made important changes to VPMAP. As a result of experiences communicated to coordinators throughout the program, the coordinators revised previously developed citizen's guides and produced a VPMAP manual, The Maine Municipal Guide to Mapping and Conserving Vernal Pools (Morgan and Calhoun 2013) to better communicate program expectations and to allow additional towns to participate in the program with minimal university assistance. The manual outlines the process of proactively managing vernal pools at the local level and addresses many of the key concerns and information needs highlighted by landowners and municipal partners throughout the planning process (e.g., details of the legislation and the process of submitting data to the state). The manual is linked to an active web page (www.umaine.edu/ vernalpools) that provides informational videos, Power-Point presentations, and forms and documents needed for the program.

While printed and on-line resources may help to clarify expectations, they do not guarantee the timely communication of PVP assessment outcomes to participating landowners. A significant bottleneck was the time-consuming process of determining "significance" at the state level. Data collected by VPMAP citizen scientists must be submitted to the State for final determination of pool "significance"; results are then passed 
on from the state to the municipality. The state is not able to process data quickly due to staffing limitations. Program coordinators did include this constraint in their public presentations, but both the towns and landowners were still frustrated by the lengthy wait for official results. A state presence at these events may have reinforced for landowners the key challenge program coordinators and municipal officials faced in evaluating PVP assessments for SVP designation. However, most participating landowners were not in attendance at these public meetings, so alternative communication platforms would need to be considered (e.g., local media outlets and postcard follow-ups to participating landowners). This may help landowners feel that they are "in-the-loop," reduce uncertainty, and most importantly keep channels of communication among program coordinators, municipal officials, and landowners open and transparent to encourage continuous engagement and avoid misunderstandings. Additional resources (e.g., staff and interns) at the town level for processing data sheets and results for submission to the state and for communicating preliminary outcomes to the landowners are critical for enhanced project success. Also critical is allocating time at project planning meetings or, if more time is needed, scheduling additional meetings to train and guide municipal officials on how they can improve communication with landowners in their town.

While these suggestions have merit, community-based citizen science programs cannot accomplish these tasks without a continuous infusion of significant human and financial resources. In implementing VPMAP, program coordinators played an important role in guiding towns through the process of community-based citizen science, but significant town support is clearly necessary for project success (e.g., a PVP database to submit to the State, increased access to private property with PVPs, enhanced visibility and understanding of 
vernal pools at the local level). Although towns supported VPMAP and participated in the program with the intent to follow through on program objectives, many towns did not have the staff time or resources to communicate with private landowners on an individual and consistent basis, particularly regarding PVP assessment outcomes. Municipalities were often unable to dedicate a single individual to VPMAP, and as a consequence officials working with the project had many other commitments. Although program coordinators and citizen scientists made an effort to engage landowners and support municipal efforts, VPMAP public meetings were poorly attended and few landowners took advantage of the opportunity to accompany citizen scientists on vernal pool assessments of their property. Instead, landowners seemed to prefer face-to-face visits with municipal officials. Based on these findings, one suggestion to improve relations between program coordinators, municipal officials, and landowners might be to establish a "landowner coordinator" at the local town level. In addition to serving as the primary point of contact between the landowner, municipal official, and the state, this position could also serve as a critical liaison to enhance coordinator-landowner outreach efforts.

To bridge the gap between scientific knowledge and conservation action, program coordinators must continuously assess how they communicate with local stakeholders and continue to learn how stakeholders use information and reach decisions about natural resources on their land and within their jurisdiction. In contrast to the "deficit model" of science communication, that relies on expert-driven public outreach to deliver information, results of citizen science assessments must be translated into formats that will improve public understanding of program outcomes (Cooper et al. 2007). This is critical for fostering landowner understanding and appreciation of the targeted resource. Community-based 
citizen science projects such as VPMAP that exist within a complex regulatory context can transcend the outdated "deficit model" by expanding opportunities to engage private landowners and municipal officials as program supporters and facilitators. This requires an expanded citizen science model that puts two-way communication with municipal officials and private landowners, as well as the training of municipal officials, on par with the recruitment, training, and data collection efforts of citizen scientists.

\section{ACKNOWLEDGMENTS}

This research was supported by National Science Foundation award EPS-0904155 to Maine EPSCoR Sustain-ability Solutions Initiative at the University of Maine, McIntire-Stennis Grant Number MEO-M-700510-13, and the USDA National Institute of Food and Agriculture. Additional support was provided by the Maine Agriculture and Forestry Experimental Station (Publication \# 3233) and the Center for Research on Sustainable Forests. 
Appendix 1: Municipal Interview Guide

1. Town/Individual Involvement

- How long has your town been involved with the mapping project?

- Will your town be participating next year?

- Could you give me some insight on why your town chose (chose not) to participate in the mapping project?

- Who in your town was ultimately responsible for making the decision to participate (or not)?

- Could you tell me your specific role in the project?

- Approximately how much time/week do you spend on the project?

2. Vernal Pools

- How would you rate your knowledge of vernal pools before the project? Now?

- What types of information/formats have been useful for you?

3. Vernal Pool Mapping Project (VPMAP)

- How did you publicize the project? Can you tell me about the landowner letter? What type of response have you received from citizen scientist volunteers? From landowners?

- Have you received any feedback on the project? From citizen scientist volunteers? From landowners? Community?

- Did you follow up with landowners who did not send back a permission form?

- How will your town use the information from the mapping project?

4. Insights

- What do you see as some of the major benefits of the project (short-term, long-term)?

- Is there anything I am missing? Things that stand out for you in the process? Major challenges? Things you would change?

- Is there anyone else you recommend I speak with?

- Could you recommend any landowners with PVP(s) who may be willing to speak with me about their experiences? 
Appendix 2: Landowner Interview Guide

1. General Information

- How long have you resided in (name of town)?

- How long have you resided at your current residence?

- Please tell me about your property.

- Tell me briefly about your involvement in your community. Are you an active member of any organizations, volunteer, or otherwise in your town?

2. Vernal Pool Mapping Project (VPMAP)

- General

- How would you rate your knowledge of vernal pools? How did you acquire this information?

- Are you aware of the vernal pool mapping project? How did you acquire this information?

- Have you attended any town planning session, town meeting, etc. where this project was discussed? How helpful was this for you? What other sources of information were helpful?

- When you learned about this project, did you have any questions or concerns? If yes, what were/are they? Did you speak to anyone about these concerns?

- Your Involvement

- What is your involvement with the mapping project? When did you become involved? What are your reasons for becoming involved (not involved) in vernal pool conservation planning?

- What was your reaction when you learned that a potential vernal pool was identified on your property?

- Have you permitted access to survey the pool to determine its significance? Why or why not?

3. Additional Insights/Other Contacts 
Appendix 3: Landowner Focus Group Guide

1. Views, Priorities, and Issues related to your Property and Community

- Why do you live in (name of town)? What qualities of this community are important to you?

- If you were to identify one issue that you think is a major concern in your town, what would that be?

- What do you like most about your property? If you were to list the top reason for why you own your property, what would that be?

- What types of activities do you do on your property?

2. Vernal Pools

- How would you rate your knowledge of vernal pools?

- What words would you use to describe vernal pools to a friend or neighbor?

- How did you first learn about vernal pools?

- How would you rate your awareness of the vernal pool project?

- Where did you learn about the project?

[HAND OUT LANDOWNER LETTER]

- Could you tell me what your response was to this letter?

- For those who participated in the vernal pool project, please tell me about your decision to participate. Could you tell me about your experiences with the project?

- For those of you not participating in the project, could you tell me more about your decision?

- What is your interest in learning about vernal pools? What kinds of things would you like to know? What questions do you have?

- Where would you go to get information on vernal pools as they relate to your property? Why this individual/ agency/organization?

- What are other useful sources of information for you?

3. Insights

- Are there any questions I forgot to ask? Issues I did not address? 
FIGURES

Figure 1 Study towns in Maine, USA

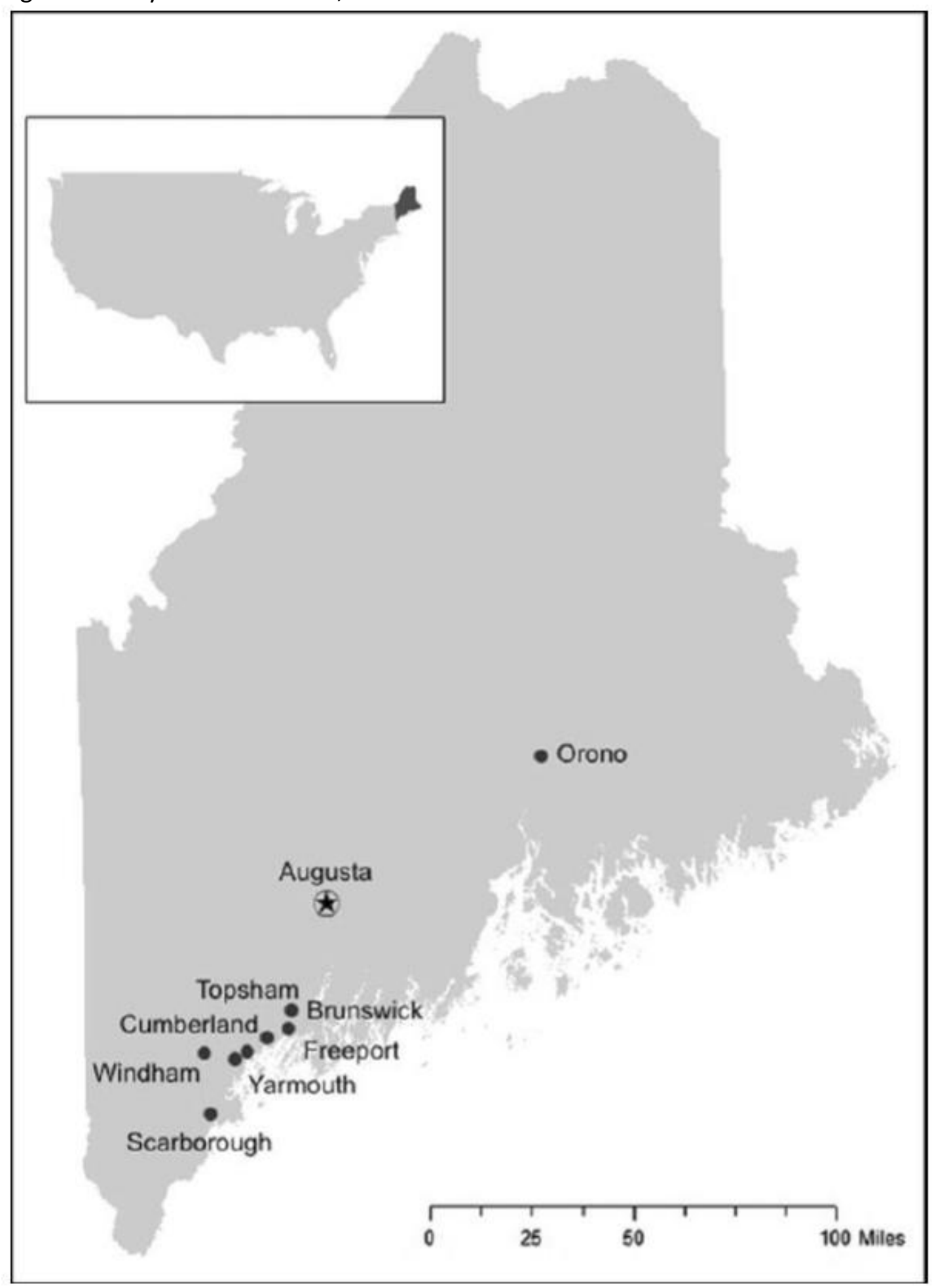


Table 1 Key findings from municipal and landowner interviews.

\begin{tabular}{|c|c|c|}
\hline Theme & $\begin{array}{l}\text { Municipal perspective of } \\
\text { VPMAP }\end{array}$ & $\begin{array}{l}\text { Landowner perspective of } \\
\text { VPMAP }\end{array}$ \\
\hline \multirow[t]{3}{*}{ Motivation } & - Proactive planning tool & $\begin{array}{l}\text { - Resource for } \\
\text { information about } \\
\text { landowner's property }\end{array}$ \\
\hline & $\begin{array}{l}\text { - Non-adversarial } \\
\text { planning approach }\end{array}$ & $\begin{array}{l}\text { - Reduce uncertainty } \\
\text { regarding development } \\
\text { options }\end{array}$ \\
\hline & $\begin{array}{l}\text { - Financial and technical } \\
\text { assistance }\end{array}$ & $\begin{array}{l}\text { - Useful tool for } \\
\text { conservation }\end{array}$ \\
\hline $\begin{array}{l}\text { Knowledge } \\
\text { and } \\
\text { awareness }\end{array}$ & $\begin{array}{l}\text { - Improved understanding } \\
\text { of ecology and } \\
\text { regulations }\end{array}$ & $\begin{array}{l}\text { - Raised awareness and } \\
\text { visibility of vernal pools } \\
\text { among landowners with } \\
\text { PVPs }\end{array}$ \\
\hline \multirow[t]{4}{*}{ Experience } & $\begin{array}{l}\text { Facilitated interaction } \\
\text { with program } \\
\text { coordinators, } \\
\text { landowners, and } \\
\text { neighboring towns on } \\
\text { vernal pool issues }\end{array}$ & $\begin{array}{l}\text { - Positive interactions } \\
\text { with citizen scientists, } \\
\text { but few landowners } \\
\text { participated in } \\
\text { assessments and public } \\
\text { meetings }\end{array}$ \\
\hline & $\begin{array}{l}\text { - Gained "hands-on" } \\
\text { experience }\end{array}$ & $\begin{array}{l}\text { - VPMAP } \\
\text { communications } \\
\text { (e.g., "landowner } \\
\text { letter") were negatively } \\
\text { received }\end{array}$ \\
\hline & $\begin{array}{l}\text { - Inconsistencies in } \\
\text { expectations of } \\
\text { municipal officials and } \\
\text { program coordinators }\end{array}$ & $\begin{array}{l}\text { - Frustration from lack of } \\
\text { follow-up with } \\
\text { landowners on PVP } \\
\text { assessment outcomes }\end{array}$ \\
\hline & $\begin{array}{l}\text { - Frustration from lack of } \\
\text { follow-up with } \\
\text { landowners on PVP } \\
\text { assessment outcomes }\end{array}$ & \\
\hline
\end{tabular}


References

Beierle TC, Cayford J (2002) Democracy in practice: public participation in environmental decisions. Resources for the Future, Washington, DC

Bernard R (2006) Research methods in anthropology: qualitative and quantitative approaches. AltiMira Press, Lanham

Bonney R, Cooper CB, Dickinson J, Kelling S, Phillips T, Rosenberg KV, Shirk J (2009) Citizen science: a developing tool for expanding science knowledge and scientific literacy. Bioscience 59:977-984

Bouchard TJ Jr (1976) Unobtrusive measures: an inventory of uses. Soc Methods Res 4:267-300

Brook A, Zint M, De Young R (2003) Landowners' responses to an Endangered Species Act listing and implications for encouraging conservation. Conserv Biol 17(6):1638-1649

Brossard D, Lewenstein BV (2010) A critical appraisal of models of public understanding of science: using practice to inform theory. In: Kahlor L, Stout PA (eds) Communicating science: new agendas in communication. Routledge, New York, pp 11-39

Busenburg GJ (1999) Collaborative and adversarial analysis in environmental policy. Policy Sci 32:1-11

Calhoun AJK, deMaynadier PG (eds) (2008) Science and conservation of vernal pools in the northeastern United States. CRC Press, Boca Raton

Calhoun AJK, Reilly P (2008) Conserving vernal pool habitat through community-based conservation. In: Calhoun AJK, de Maynadier PG (eds) Science and conservation of vernal pools in the northeastern United States. CRC Press, Boca Raton, pp 319-336

Carr A, Hazell D (2006) Talking frogs: the role of communication in ecological research on private land. Biodivers Conserv 15(10):3177-3191

Cash DW, Clark WC, Alcock F, Dickson NM, Eckley N, Guston DH, Jager J, Mitchell RB (2003) Knowledge for sustainable development. Proc Natl Acad Sci 100(4):8086-8091

Cooper CB, Dickinson J, Phillips T, Bonney R (2007) Citizen science as a tool for conservation in residential ecosystems. Ecol Soc 12(2):11

Crall AW, Newman GJ, Jarnevich CS, Stohlgren TJ, Waller DM, Graham J (2010) Improving and integrating data on invasive species collected by citizen scientists. Biol Invasions 12:3419-3428

Dale VH, Brown S, Haeuber RA, Hobbs NT, Huntly N, Naiman RJ, Riebsame WE, Turner MG, Valone TJ (2000) Ecological principles for managing the use of land. Ecol Appl 10(3):639-670

Danielson F, Burgess ND, Balford A (2005) Monitoring matters: examining the potential of locally-based approaches. Biodivers Conserv 14:2507-2542

Evans C, Abrams E, Reitsma R, Roux K, Salmonsen L, Marra PP (2005) The neighborhood nestwatch program: participant outcomes of a citizen science ecological research project. Conserv Biol 19:589-594

Fox HE, Christian C, Nordby JC, Pergams ORW, Peterson GD, Pyke CR (2006) Perceived barriers to integrating social science and conservation. Conserv Biol 20(6):1817-1820 
Glaser BG, Strauss AL (1967) The discovery of grounded theory: strategies for qualitative research. Aldine, Chicago Glesne C (2006) Becoming qualitative researchers. Allyn \& Bacon, Boston

Groffman PM, Styliniski C, Nisbet MC, Duarte M, Jordan R, Burgin A, Prentali MA, Coloso J (2010) Restarting the conversation: challenges at the interface between ecology and society. Front Ecol Environ 8(6):284-291

Hall JA, Fleishman E (2009) Demonstration as a means to translate conservation science into practice. Conserv Biol 24(1):120-127

Hart DD, Calhoun AJK (2010) Rethinking the role of ecological research in the sustainable management of freshwater ecosystems. Freshw Biol 55(1):258-269

Hilty J, Merenlender AM (2003) Studying biodiversity on private lands. Conserv Biol 17(1):132-137

Ingwell LL, Preisser EL (2010) Using citizen science programs to identify host resistance in pestinvaded forests. Conserv Biol 25(1):182-188

Jansujwicz JS, Calhoun AJK, Leahy JE, Lilieholm RJ (2013) Using mixed methods to develop a frame-based private landowner typology. Soc Nat Resour 26(8):945-961

Jenkins CW (1999) School, science, citizenship, and public understanding of science. Int J Sci Educ 21(7):703-710

Kamberelis G, Dimitriadis G (2005) Focus groups: strategic articulations of pedagogy, politics and inquiry. In: Denzin NK, Lincoln YS (eds) Handbook of qualitative research. Sage Publications, Thousand Oaks, pp 887-907

Knight AT, Cowling RM, Rouget M, Balmford A, Lombard AT, Campbell BM (2008) Knowing but not doing: selecting priority conservation areas and the research-implementation gap. Conserv Biol 22(3):610-617

Kransy M, Bonney R (2005) Environmental education through citizen science and participatory action research. In: Johnson EA, Mappin MJ (eds) Environmental education or advocacy: perspectives of ecology and education in environmental education.

Cambridge University Press, Cambridge

Lepczyk CA (2005) Integrating published data and citizen science to describe bird biodiversity across a landscape. J Appl Ecol 42:672-677

Lewenstein BV (2003) Popularization. In: Heilbron JL (ed) Oxford companion to history of modern science. Oxford University Press, Oxford

Meffe GK, Ehrenfeld D, Noss RF (2006) Conservation biology at twenty. Conserv Biol 20(3):595-596

Merriam SB (2009) Qualitative research: a guide to design and implementation. Wiley, San Francisco

Miller-Rushing A, Primack R, Bonney R (2012) The history of public participation in ecological research. Front Ecol Environ 10(6):285-290

Morgan DE, Calhoun JK (2013) The Maine municipal guide to mapping and conserving vernal pools. Maine Audubon Society, Gilsland

Neuman WL (2000) Social research methods. Allyn and Bacon, Boston 
Nisbet MC, Scheufele DA (2009) What's next for science communication? Promising directions and lingering distractions. Am J Bot 96(10):1767-1778

Novacek MJ (2008) Engaging the public in biodiversity issues. Proc Natl Acad Sci 105(1):11571-11578

Oscarson DB, Calhoun AJK (2007) Developing vernal pool conservation plans at the local level using citizen-scientists. Wetlands 27(1):80-95

Reyers B, Roux DJ, Ginsburg AE, Nel JL, O'Farrell P (2010) Conservation planning as a transdisciplinary process. Conserv Biol 24(4):957-965

Rowe G, Frewer L (2000) Public participation methods: a framework for evaluation. Sci Technol Hum Values 25(1):3-29

Saldaña J (2009) The coding manual for qualitative researchers. Sage Publications, Thousand Oaks

Silvertown J (2009) A new dawn for citizen science. Trends Ecol Evol 24(9):467-470

Strauss AC, Corbin JM (1990) Basics of qualitative research: grounded theory procedures and techniques. Sage Publications, Thousand Oaks

Sturgis P, Allum N (2004) Science in society: re-evaluating the deficit model of public attitudes. Public Underst Sci 13:55-74 Trumbull DJ, Bonney R, Bascom D, Cabral A (2000) Thinking scientifically during participation in a citizen science project. Sci Educ $84: 25-27$

USDA (2002) Major uses of land in the United States. USDA Economic Research Service EIB-14, Washington, DC

Weckel ME, Mack D, Nagy C, Christie R, Wincorn A (2010) Using citizen science to map human-coyote interactions in suburban New York, USA. J Wildl Manag 74(5):1163-1171

Ziman J (1991) Public understanding of science. Sci Technol Hum Values 16(1):99-105

Ziman J (1992) Not knowing, needing to know, and wanting to know. In: Lewenstein BV (ed) When science meets the public.

American Association for the Advancement of Science, Washington, D.C., pp 13-20 